\title{
Are vitamin D and vitamin D receptor levels different in children with developmental dysplasia of the hip?
}

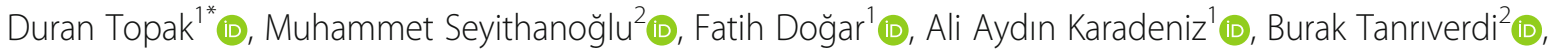
Fırat Ozan ${ }^{3}$ (D) and Ökkeş Bilal ${ }^{1}$ (D)

\begin{abstract}
Introduction: Developmental dysplasia of the hip (DDH) is a common disorder and associated with significant morbidity of the hip joint. Several risk factors have been identified for DDH. The aim of this study is to investigate whether vitamin D and vitamin D receptor (VDR) levels differ in children with DDH and whether they have an effect on DDH development.

Materials and methods: A total of 40 (17 males, 23 females; 9 right hips, 16 left hips, 15 bilateral hips) children who were treated for developmental dysplasia and 40 (23 males, 17 females) healthy children without any musculoskeletal system and metabolic disorders were included in this study between January and June 2019. Blood samples from the DDH and control groups of children were collected to measure the serum levels of vitamin D, VDR, calcium (Ca), phosphorus (P), and alkaline phosphatase (ALP). The levels of Ca, P, and ALP were analyzed using the automated standard spectrophotometric laboratory method. The levels of vitamin D and VDR in the samples were analyzed using enzyme-linked immunoassay.

Results: There were no significant differences in the serum levels of $C a, P, A L P$, and vitamin D between the DDH and healthy groups (Ca $9.96 \pm 0.47$ vs. $9.92 \pm 0.48 \mathrm{mg} / \mathrm{dL}$, respectively, $p=0.721 ; P 5.3 \pm 0.94$ vs. $4.82 \pm 0.88 \mathrm{mg} / \mathrm{dL}$, respectively, $p=0.23$; ALP $252.22 \pm 170.15$ vs. $245.3 \pm 130.93 \mathrm{U} / \mathrm{L}$, respectively, $p=0.839$ ). However, serum VDR levels were significantly lower in children in the DDH group $(5.77 \pm 3.51 \mathrm{ng} / \mathrm{mL})$ than in the healthy control group $(9.25 \pm$ $6.43 \mathrm{ng} / \mathrm{mL})(p=0.004)$.
\end{abstract}

Conclusions: In conclusion, we believe that low VDR levels can affect DDH regardless of the serum levels of Ca, P, ALP, and vitamin D. More comprehensive studies involving parents are needed to understand whether VDR levels mediate genetic transmission in DDH or not.

Keywords: Developmental dysplasia of the hip, Risk factor, Vitamin D receptor, Vitamin D

\footnotetext{
* Correspondence: drdtopak@gmail.com

${ }^{1}$ Faculty of Medicine, Department of Orthopaedic and Traumatology,

Kahramanmaras Sutcu Imam University, Kahramanmaras, Turkey

Full list of author information is available at the end of the article
}

(c) The Author(s). 2021 Open Access This article is licensed under a Creative Commons Attribution 4.0 International License, which permits use, sharing, adaptation, distribution and reproduction in any medium or format, as long as you give appropriate credit to the original author(s) and the source, provide a link to the Creative Commons licence, and indicate if changes were made. The images or other third party material in this article are included in the article's Creative Commons licence, unless indicated otherwise in a credit line to the material. If material is not included in the article's Creative Commons licence and your intended use is not permitted by statutory regulation or exceeds the permitted use, you will need to obtain permission directly from the copyright holder. To view a copy of this licence, visit http://creativecommons.org/licenses/by/4.0/. The Creative Commons Public Domain Dedication waiver (http://creativecommons.org/publicdomain/zero/1.0/) applies to the data made available in this article, unless otherwise stated in a credit line to the data. 


\section{Introduction}

Developmental dysplasia of the hip (DDH) is a common disorder and associated with significant morbidity of the hip joint [1-3]. Early identification of DDH can provide early correction of the anatomy of the hip, thereby leading to recovery without the need for any major reconstructive surgery (Fig. 1) [1, 2, 4].

The incidence of DDH has been reported to be between 1.6 and 28.5 per 1000 neonates [2]. The majority of children with DDH are females, and the left hip is generally affected, $20 \%$ of the cases being bilateral $[1-3,5]$. The risk factors for DDH include breech presentation, positive family history, sex, oligohydramnios, prematurity, low birth weight, and amniotic fluid abnormalities $[1-3,5]$.

The importance of early diagnosis has been confirmed in the treatment of DDH $[1,2]$. Currently, DDH screening is performed by clinical examination (Ortholani maneuver, Barlow provocative test, and abduction restriction), ultrasound scanning, or radiography for patients at risk. Although ultrasound has been recommended as a screening test $[1,3]$, it is not significantly better than at-risk or selective screening [3]. Therefore, it would be highly desirable to identify the predictors of DDH in a high-risk population.

Numerous studies have investigated vitamin $\mathrm{D}$ as a risk factor in several diseases [6-11]. In addition to its effects on mineral metabolism, vitamin D exerts its effects on different systems. Vitamin D deficiency has been associated with different diseases such as skeletal system disorders, brain dysfunction, cellular dysfunction, chronic kidney disease, diabetes, disorders of immune response, cancer, abnormalities in the mechanism of insulin release and glucose tolerance, neuromuscular function disorders, and heart failure. Moreover, its association with morbidity, especially in children with DDH, can be significant [3, 6-11]. Vitamin D receptors (VDRs) are found in almost all tissues in the body, and all biological actions of vitamin $\mathrm{D}$ are mediated by its binding to VDR $[6,9]$.

The aim of this study is to investigate whether vitamin $\mathrm{D}$ and vitamin $\mathrm{D}$ receptor (VDR) levels differ in children with DDH and whether they have an effect on DDH development.

\section{Materials and methods}

Eighty patients were included in the study, which is an observational, prospective, case-control type study. Children of 6 to 90 months old were divided into two groups. A total of 40 (17 males, 23 females; 9 right hips, 16 left hips, 15 bilateral hips) children who were treated for developmental dysplasia (group DDH) and 40 (23 males, 17 females) healthy children (group control) were included in this study from January to June 2019. DDH was diagnosed on the basis of clinical criteria and ultrasound and radiographic examinations depending on the age. Healthy children consisted of patients who applied to the pediatric clinic for routine control, and they did not have any family history of DDH or hip disorders. All of the children in the DDH and control groups consist of children living in the Turkish race and Eastern Mediterranean region. The venous blood of the children in both groups was taken once between eight and ten o'clock in the morning.

The inclusion criteria for this study are as follows: children diagnosed with DDH between 6 and 90 months and completely healthy children without any orthopedic, genetic, and chronic diseases in the same age group. Exclusion criteria for this study are as follows: vitamin D and calcium $(\mathrm{Ca})$ absorption disorders (metabolic bone disease, chronic kidney failure, genetic disorders, epiphyseal dysplasia), children with musculoskeletal anomalies, and children whose parents did not give consent to participate in the study

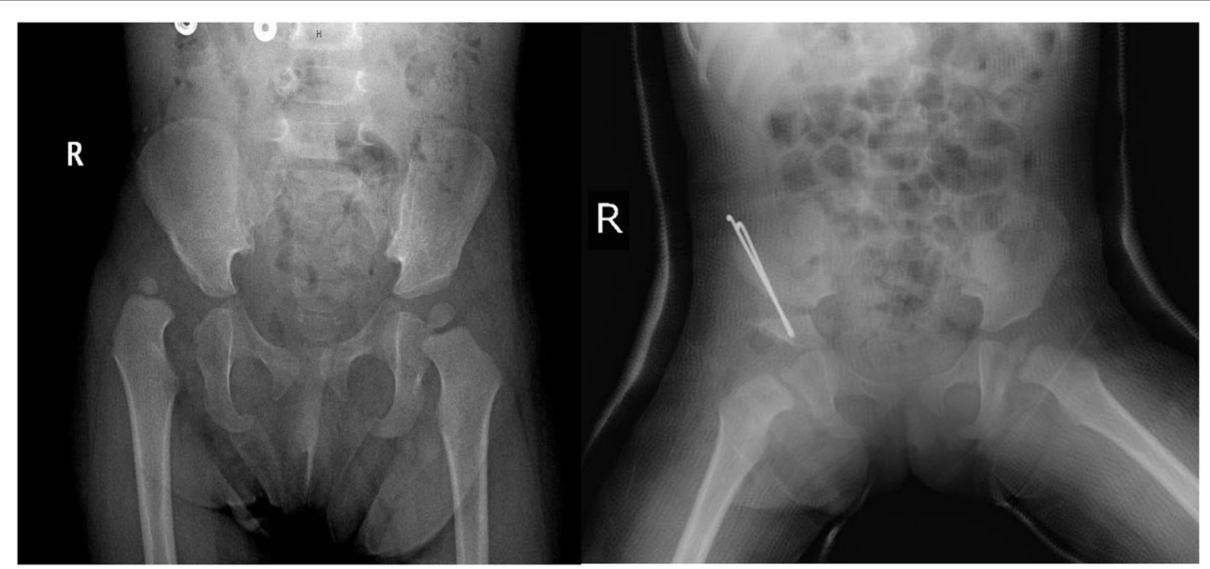

Fig. 1 Twenty-one-month-old female, right DDH preoperative and postoperative X-ray images 
This research protocol was approved by our local Ethics Committee. Written informed consent was obtained from all subjects before their inclusion in the study (session: 2019/14; date: 31 July 2019; decision no: 11). Informed consent of children was obtained from their families.

\section{Blood sample collection}

The venous blood of the children in both groups was taken once between eight and ten o'clock in the morning. The venous blood taken by the phlebotomy method was placed in tubes without anticoagulants. The serum and plasma were obtained by centrifuging the collected blood for $10 \mathrm{~min}$ at $4000 \mathrm{rpm}$. The serum and plasma obtained were stored at $-80{ }^{\circ} \mathrm{C}$ until the working day. On the working day, all samples were brought to room temperature. Serum vitamin D receptor levels were determined using commercial ELISA kit procedures (EEL-H2043; Elabscience, USA). Measurement of 25-OH vitamin $\mathrm{D}$ in the plasma obtained was determined with a UV detector on the HPLC device (Thermo Ultimate 3000, USA) using the Vitamin D ClinRep HPLC kit (Recipe Chemicals Instruments, Munich, Germany). Serum calcium, alkaline phosphatase, and phosphorus levels were measured with original kits of Siemens Advia 1800 (Siemens Healthcare $\mathrm{GmbH}$ ) biochemistry autoanalyzer.

\section{Statistical analysis}

Statistical analysis was performed using IBM SPSS 21.0 (IBM, Armonk, NY, USA). Frequency analysis was performed for categorical variables. Data were expressed as numbers and percentages. Pearson's chi-square tests were performed to compare the categorical data. $p<$ 0.05 was considered as statistically significant.

Multivariate analysis was performed to compare the dependent variables in two independent groups (MANOVA). In the test, it was seen that the two groups were homogeneously distributed, and the equality was impaired only by VDR levels $(p=0.001)$. In the multivariate test, there was $p=0.002$ in the Wilks lambda test, and there was a significant difference between the two groups.

\section{Results}

Table 1 shows the characteristics and clinical outcomes of the patients. The mean ages of children in the DDH and healthy control groups were $33.62 \pm 22.6$ months (range, 6-72 months) and $42.92 \pm 21.95$ months (range, $8-72$ months), respectively ( $p=0.066)$. Eight $(20 \%)$ patients in the DDH group had a family history. There were no significant differences in the levels of $\mathrm{Ca}$, phosphorus (P), and alkaline phosphatase (ALP) between the $\mathrm{DDH}$ and healthy groups (Ca $9.96 \pm 0.47$ vs. $9.92 \pm 0.48$ $\mathrm{mg} / \mathrm{dL}$, respectively, $p=0.721 ;$ P $5.3 \pm 0.94$ vs. $4.82 \pm$ $0.88 \mathrm{mg} / \mathrm{dL}$, respectively, $p=0.230$; ALP $252.22 \pm 170.15$ vs. $245.3 \pm 130.93 \mathrm{U} / \mathrm{L}$, respectively, $p=0.839$ ).

The mean serum vitamin D levels in the DDH and healthy control groups were $20 \pm 14.26$ and $22.65 \pm$ $13.36 \mathrm{ng} / \mathrm{mL}$, respectively $(p=0.394)$. The serum VDR levels were significantly lower in children in the DDH group $(5.77 \pm 3.51 \mathrm{ng} / \mathrm{mL})$ than in the healthy control group $(9.25 \pm 6.43 \mathrm{ng} / \mathrm{mL})(p=0.004)$.

\section{Discussion}

In this study, we attempted to shed light on the relationship between DDH and levels of vitamin D and VDR. We found that the serum levels of vitamin D and VDR in children with DDH were lower than those in healthy children. Furthermore, there were no significant differences between the DDH and control groups in terms of serum levels of $\mathrm{Ca}, \mathrm{P}$, and ALP. To our knowledge, this is the first study to evaluate the relationship between VDR levels and DDH in children in the literature.

Vitamin D is classically responsible for the regulation of calcium metabolism, promoting growth and proper remodeling of bones $[5,6,9]$. However, vitamin $\mathrm{D}$ also has autocrine or paracrine effects in other extrarenal tissues such as the skin, prostate, lymph nodes, intestine,

Table 1 Demographic characteristics and clinical outcomes

\begin{tabular}{|c|c|c|c|}
\hline & DDH group $(n=40)$ & Control group $(n=40)$ & $p$ value \\
\hline Age (months), mean (range) & $33.6(6-72)$ & $42.9(8-72)$ & 0.066 \\
\hline \multicolumn{4}{|l|}{ Sex, $n(\%)$} \\
\hline Female & $23(57.5)$ & $17(42.5)$ & \multirow[t]{2}{*}{0.180} \\
\hline Male & $17(42.5)$ & $23(57.5)$ & \\
\hline $25-\mathrm{OH}$ vitamin $\mathrm{D}(\mathrm{ng} / \mathrm{mL})$, mean & 20 & 22.6 & 0.394 \\
\hline Vitamin D receptor $(\mathrm{ng} / \mathrm{mL})$, mean & 5.7 & 9 & 0.004 \\
\hline Calcium (mg/dL), mean & 9.9 & 9.9 & 0.721 \\
\hline Phosphorus (mg/dL), mean & 5.3 & 4.8 & 0.230 \\
\hline Alkaline phosphatase $(U / L)$, mean & 252.2 & 245 & 0.839 \\
\hline
\end{tabular}

$\overline{D D H}$ developmental dysplasia of the hip 
breast, pancreas, central nervous system, immune system, placenta, and the circulatory system $[6,8-11]$. Because of its complex functions, several studies have investigated the association between the genes and proteins in the vitamin $\mathrm{D}$ endocrine system with some diseases $[7,10,11]$.

All biological actions of vitamin $\mathrm{D}$ are mediated by its binding to VDR. VDRs are found in almost all tissues in the body [9]. It is a major factor in the endocrine system, which regulates calcium metabolism and absorption along with other important cellular functions [12].

DDH exhibits multifactorial and etiopathological features. Family studies conducted on DDH have shown that this disease has a genetic component and complies with the autosomal dominant inheritance pattern [7].

Some studies have investigated the genetic basis of DDH via the VDR gene [3]. The VDR gene has important roles in bone mineralization and vitamin $\mathrm{D}$ metabolism. Furthermore, polymorphisms in the VDR gene have been linked to osteoporosis [13]. Granchi et al. found an association between osteoarthritis secondary to DDH and the VDR polymorphism Bsm I. They suggested that the VDR gene is involved in the etiology of DDH [14]. However, Kapoor et al. reported that there were possible genetic associations between DDH and VDR polymorphisms [3]. In contrast, Jawadi et al. demonstrated that there were no associations between VDR polymorphisms and DDH [7].

In the present study, no significant differences were found in the serum levels of Ca, P, ALP, and vitamin D in both the DDH and control groups of children. Although these parameters were within normal limits, it has been demonstrated that mutations associated with the VDR gene may inhibit vitamin D metabolism $[3,6]$. Vitamin D exerts its effects by binding to VDR, which is found in various tissues [6]. In this study, serum VDR levels were found to be significantly lower in children with DDH than in the control children.

The fact that the cases were selected from the same region and race was seen as the limitation of this study.

In conclusion, we believe that low VDR levels can affect DDH regardless of the serum levels of Ca, P, ALP, and vitamin D. More comprehensive studies involving parents are needed to understand whether VDR levels mediate genetic transmission in DDH or not.

\section{Abbreviations}

DDH: Developmental dysplasia of the hip; VDR: Vitamin D receptor; Ca: Calcium; P: Phosphorus; ALP: Alkaline phosphatase; VDRs: Vitamin D receptors

\section{Acknowledgements}

We would like to thank ENAGO (http://www.enago.com.tr) translation services for their contribution to the translation and editing of the article.

\section{Animal and human rights statement}

All procedures performed in this study were in accordance with the ethical standards of the institutional and/or national research committee and with the 1964 Declaration of Helsinki and its later amendments or comparable ethical standards. No animal or human studies were carried out by the authors of this article.

None of the authors received any type of financial support that could be considered a potential conflict of interest regarding the manuscript or its submission.

\section{Authors' contributions}

Duran Topak, Muhammet Seyithanoğlu, and Fatih Doğar constructed the idea or hypothesis for the research. Duran Topak took the responsibility of drafting the whole manuscript. Ökkeş Bilal and Ali Aydın Karadeniz reviewed the article before submission not only for spelling and grammar but also for its intellectual content. Fatih Doğar and Fırat Ozan took the responsibility of drafting the project and the ethics paper. Duran Topak and Burak Tanriverdi took the responsibility of the execution of the experiments, data management, and reporting. All authors reviewed and approved the final manuscript.

\section{Funding}

The authors did not declare any specific grant from funding agencies in the public, commercial, or not-for-profit sectors in this article.

\section{Availability of data and materials}

The data and materials of patients participating in this study are available to us and will be provided by us upon request.

\section{Ethics approval and consent to participate}

This research protocol was approved by our local Ethics Committee. Written informed consent was obtained from all subjects before their inclusion in the study (session: 2019/14; date: 31 July 2019; decision no: 11). Informed consent of children was obtained by their families. The manuscript has been read and approved by all authors, and the requirements for authorship have been met. Furthermore, each author believes that the manuscript represents honest work. This manuscript has not been published elsewhere and is not under consideration by another journal.

Consent for publication

All authors have agreed to publish this content in your journal.

\section{Competing interests}

The authors declare that there is no conflict of interest.

\section{Author details}

${ }^{1}$ Faculty of Medicine, Department of Orthopaedic and Traumatology, Kahramanmaras Sutcu Imam University, Kahramanmaras, Turkey. ${ }^{2}$ Faculty of Medicine, Department of Biochemistry, Kahramanmaras Sutcu Imam University, Kahramanmaras, Turkey. ${ }^{3}$ Department of Orthopedics and Traumatology, Kayseri Training and Research Hospital, Kayseri, Turkey.

Received: 28 September 2020 Accepted: 14 December 2020 Published online: 07 January 2021

\section{References}

1. Vaquero-Picado A, González-Morán G, Garay EG, Moraleda L. Developmental dysplasia of the hip: update of management. EFORT Open Rev. 2019;4:548-56.

2. Shorter D, Hong T, Osborn DA. Cochrane review: screening programmes for developmental dysplasia of the hip in newborn infants. Evid Based Child Health. 2013;8(1):11-54.

3. Kapoor B, Dunlop C, Wynn-Jones C, Fryer AA, Strange RC, Maffulli N. Vitamin $\mathrm{D}$ and oestrogen receptor polymorphisms in developmental dysplasia of the hip and primary protrusio acetabuli - a preliminary study. J Negat Results Biomed. 2007;6:7

4. Ozan F, Uzun E, Gürbüz K, Koyuncu Ş, Altay T, Kayalı C. Total hip arthroplasty in the developmental dysplasia of the hip using transverse subtrochanteric osteotomy. J Orthop. 2016;13(4):259-63.

5. Rubini M, Cavallaro A, Calzolari E, Bighetti G, Sollazzo V. Exclusion of COL2A1 and VDR as developmental dysplasia of the hip genes. Clin Orthop Relat Res. 2008;466(4):878-83. 
6. Sahin N, Altun H, Kurutas EB, Balkan D. Vitamin D and vitamin D receptor levels in children with attention-deficit/hyperactivity disorder. Neuropsychiatr Dis Treat. 2018;14:581-5.

7. Jawadi AH, Wakeel A, Tamimi W, Nasr A, labal Z, Mashhour A, Fattah MA, Alkhanein $N$, Abu Jaffal AS. Association analysis between four vitamin D receptor gene polymorphisms and developmental dysplasia of the hip. J Genet. 2018;97(4):925-30

8. Altun $H$, Kurutaş EB, Şahin N, Güngör O, Fındıklı E. The levels of vitamin D, vitamin $\mathrm{D}$ receptor, homocysteine and complex B vitamin in children with autism spectrum disorders. Clin Psychopharmacol Neurosci. 2018;16(4):383-90.

9. Bover J, Egido J, Fernández-Giráldez E, Praga M, Solozábal-Campos C, Torregrosa JV, Martínez-Castelao A. Vitamin D, vitamin D receptor and the importance of its activation in patients with chronic kidney disease. Nefrologia. 2015;35(1):28-41.

10. Gandini S, Gnagnarella P, Serrano D, Pasquali E, Raimondi S. Vitamin D receptor polymorphisms and cancer. Adv Exp Med Biol. 2014;810:69-105.

11. Hayes CE, Nashold FE, Spach KM, Pedersen LB. The immunological functions of the vitamin D endocrine system. Cell Mol Biol (Noisy-le-grand). 2003; 49(2):277-300.

12. Uitterlinden $A G$, Fang $Y$, van Meurs JB, Pols HA, van Leeuwen JP. Genetics and biology of vitamin D receptor polymorphisms. Gene. 2004;338:143-56.

13. Wu J, Shang DP, Yang S, Fu DP, Ling HY, Hou SS, Lu JM. Association between the vitamin $\mathrm{D}$ receptor gene polymorphism and osteoporosis. Biomed Rep. 2016;5:233-6.

14. Granchi D, Stea S, Sudanese A, Toni A, Baldini N, Giunti A. Association of two gene polymorphisms with osteoarthritis secondary to hip dysplasia. Clin Orthop Relat Res. 2002;403:108-17.

\section{Publisher's Note}

Springer Nature remains neutral with regard to jurisdictional claims in published maps and institutional affiliations.

Ready to submit your research? Choose BMC and benefit from:

- fast, convenient online submission

- thorough peer review by experienced researchers in your field

- rapid publication on acceptance

- support for research data, including large and complex data types

- gold Open Access which fosters wider collaboration and increased citations

- maximum visibility for your research: over $100 \mathrm{M}$ website views per year

At $\mathrm{BMC}$, research is always in progress.

Learn more biomedcentral.com/submissions 